\title{
Artikel
}

\section{Medewerking door ondernemingen aan een strafrechtelijk onderzoek}

\author{
Nopen nieuwe ontwikkelingen tot invoering van Nederlands beleid voor interne onderzoeken?
}

\section{Inleiding}

In de zomer van 2019 bestond in Nederland relatief veel aandacht voor de interne onderzoekspraktijk. Het Financieele Dagblad kopte in juni 'Fustitie laat fraudeonderzoek vaker over aan advocaten van bedrijven zelf en 'In de ideale situatie is onderzoek van de Fiod niet eens meer nodig'. ${ }^{1}$ De berichtgeving leidde tot diverse reacties van professionals werkzaam op dit terrein, alsook tot Kamervragen. De praktijk waarbij bedrijven die worden geconfronteerd met mogelijke onregelmatigheden een onderzoek laten uitvoeren door advocaten en/of accountants (hierna: 'interne onderzoeken' of 'interne onderzoekspraktijk') is evenwel niet nieuw. De hernieuwde aandacht ontstond omdat in de artikelen expliciet aan de orde kwam dat interne onderzoeken ook uitgevoerd kunnen worden nadat de FIOD en het Openbaar Ministerie (hierna: 'OM') zich reeds bij de verdachte onderneming hebben gemeld. Ook dat is niet nieuw, maar wel dat FIOD en OM onder omstandigheden bereid blijken de uitkomst van het interne onderzoek af te wachten, alvorens te besluiten tot het verrichten van eigen (verdere) onderzoekshandelingen. Onder vakgenoten werd deze ontwikkeling ook wel aangeduid als 'Internal Investigations 2.0'. ${ }^{2}$ De resultaten van het interne onderzoek worden vervolgens aan de FIOD en het OM verstrekt, in de verwachting dat dit een positieve invloed heeft op de wijze van afdoening, en tegelijkertijd betekent dat mogelijk bepaalde onderzoekshandelingen door de FIOD en het OM niet meer hoeven te worden verricht.

Het OM heeft geen beleid gepubliceerd op basis waarvan vooraf duidelijk is of een verdachte aanspraak kan maken op een bepaalde wijze van afdoening of matiging van de sanctie (hierna: 'incentives') bij medewerking aan een strafrechtelijk onderzoek (paragraaf 2). Medewerking omvat in dit artikel dat de onderneming een intern onderzoek laat uitvoeren, waarvan de resultaten worden verstrekt aan de autoriteiten (hierna: 'medewerking'). In de Verenigde Staten van Amerika (hierna: 'VS') bestaat al langer beleid, vastgelegd in onder andere de FCPA Corporate Enforcement Policy, om zelfmelding en medewerking aan een strafrechtelijk onderzoek te stimuleren (paragraaf 3). Het Verenigd Koninkrijk (hierna: 'VK') heeft in augustus 2019 beleid gepubliceerd over medewerking door verdachte ondernemingen (paragraaf 4). Tot slot heeft Duitsland een wetsvoorstel in ontwikkeling, waarin incentives zijn vastgelegd voor verdachte ondernemingen, alsook regels over de uitvoering van een intern onderzoek. In dit artikel worden de verschillende kaders op hoofdlijnen in beeld gebracht en wordt beoordeeld of het raadzaam is in Nederland vergelijkbaar beleid in te voeren als in de VS, het VK of Duitsland. 


\section{Geen beleid in relatie tot interne onderzoeken in de Nederlandse praktijk}

\subsection{Inleiding}

Minister Grapperhaus van Justitie en Veiligheid (hierna: 'de minister') heeft in antwoord op Kamervragen van Van Nispen (SP) en Groothuizen (D66) in juni $2019^{3}$ bericht dat hij onderzoeken uitgevoerd door advocaten of (forensisch) accountants als een middel ziet om op een 'zo effectief en efficiënt mogelijke wijze' een complex strafrechtelijk onderzoek aan te pakken. ${ }^{4}$ De minister merkte op dat het $\mathrm{OM}$ zelfmelding ${ }^{5}$ en medewerking aan het feitenonderzoek door bedrijven, maar ook door natuurlijke personen, in de regel positief meeweegt bij de afdoening van de strafzaak. ${ }^{6}$ Thomas Bosch, landelijk coördinerend officier fraude bij het Functioneel Parket, bevestigde dat het OM graag ziet dat ondernemingen zelf hun rotzooi opruimen en ook zorgen dat het niet meer gebeurt. Als ondernemingen dat met overtuiging doen en meewerken aan het onderzoek van het OM, dan weegt het $\mathrm{OM}$ dat positief mee bij de afdoening. ${ }^{7}$ De minister bevestigde in antwoord op Kamervragen in april 2019 dat het $\mathrm{OM}$ in de toekomst vaker gebruik wil maken van onafhankelijk onderzoek door professionals, waaronder advocaten of (forensisch) accountants, die door verdachte bedrijven zelf zijn ingehuurd. ${ }^{8}$

\subsection{Geen beleid met daarin incentives}

Hoewel zowel de minister als het OM positief staat tegenover medewerking aan strafrechtelijke onderzoeken, zelfmelding en het uitvoeren van interne onderzoeken in opdracht van de verdachte onderneming, bestaat in Nederland geen beleid waarin incentives zijn vastgelegd om een bedrijf daartoe te stimuleren. Uit de persberichten van het $\mathrm{OM}$ van de afgelopen jaren inzake de zogeheten hoge transacties ${ }^{9}$ met bedrijven verdacht van fraude kan wel worden afgeleid dat het OM zelfmelding, medewerking aan het onderzoek, getroffen herstelmaatregelen en aanscherping van complianceprogramma's positief meeweegt bij besluiten om een transactie aan te bieden. Uit de persberichten van de transacties getroffen met onder andere SBM Offshore, Vimpelcom en Telia Company blijkt welke elementen positief hebben meegewogen bij de besluitvorming om over

3. Kamervragen Van Nispen (SP) en Groothuizen (D66), 6 juni 2019, nr. 2019211430.

4. Antwoord Minister van Veiligheid en Justitie op Kamervragen, brief 6 september 2019, kenmerk 2662527, p. 3.

5. Met het begrip 'zelfmelding' wordt in dit artikel bedoeld het door de onderneming zelf melden van de onregelmatigheid bij het $\mathrm{OM}$, voordat het $O M$ hiervan op de hoogte is.

6. Antwoord Minister van Veiligheid en Justitie op Kamervragen, brief 6 september 2019, kenmerk 2662527.

7. Het Financieele Dagblad, 'Justitie laat fraudeonderzoek vaker over aan advocaten van bedrijven zelf', 4 juni 2019.

8. Antwoord Minister van Veiligheid en Justitie op Kamervragen over de betrouwbaarheid en volledigheid van zelfonderzoek door eigen advocaten van bedrijven, brief 8 april 2020, 2869478.

9. Aanwijzing hoge transacties en bijzondere transacties, Stcrt 2008, 209. te gaan tot deze buitengerechtelijke afdoening. ${ }^{10}$ Echter, bij gebrek aan een vastgelegd beleid op dit punt kan een onderneming geen aanspraak maken op een bepaalde wijze van afdoening of concrete matiging van de sanctie.

\subsection{Geen beleid over uitvoering van het onderzoek}

In Nederland zijn ook geen richtlijnen opgesteld waaraan een intern onderzoek moet voldoen. De minister gaf aan dat bij onderzoeken door advocaten of accountants die door verdachte bedrijven zelf zijn ingehuurd, door het OM wel bepaalde randvoorwaarden in acht worden genomen bij het waarderen van het onderzoek. ${ }^{11}$ Zo zal het OM dit onderzoek altijd door de FIOD laten controleren op 'diepgang en volledigheid'. ${ }^{12}$ Of een feitenonderzoek diepgaand en volledig genoeg is, is afhankelijk van de feiten en omstandigheden van het specifieke geval. Om die reden ligt het volgens de minister niet in de rede om een formele richtlijn voor te schrijven waaraan het interne onderzoek moet voldoen. ${ }^{13}$

De minister heeft in antwoord op de eerder aangehaalde Kamervragen bericht dat ook een advocaat die al andere werkzaamheden voor de onderneming heeft verricht een intern onderzoek kan uitvoeren, waarvan de resultaten aan de FIOD en het OM worden verstrekt. De minister merkt daarbij op dat advocaten zich dienen te houden aan de Advocatenwet en de daaruit voortvloeiende beroeps- en gedragsregels, welke volgens de minister onder meer inhouden dat advocaten 'bij het uitvoeren van het onderzoek voldoende onafhankelijkheid dienen te betrachten ten opzichte van hun opdrachtgever' ${ }^{14}$ Dit heeft de minister nog eens bevestigd bij beantwoording van Kamervragen op 8 april 2020. Daarbij overwoog de minister tevens dat gelet op de gehanteerde randvoorwaarden eventuele risico's die gepaard kunnen gaan met op verzoek van de verdachte onderneming uitgevoerde onderzoeken naar zijn mening in voldoende mate worden gemitigeerd. ${ }^{15}$

10. Zie onder andere persberichten SBM Offshore (https://www.om.nl/ actueel/nieuws/2014/11/12/sbm-offshore-n.v.-betaalt-ususd240.000.000-wegens-omkoping), Vimpelcom (https://www.om.nl/actu eel/nieuws/2016/02/18/vimpelcom-betaalt-bijna-400-miljoen-dollaraan-nederland-voor-omkoping-in-oezbekistan), Telia Company (https://www.om.nl/actueel/nieuws/2017/09/21/internationale-strijdtegen-corruptie-telia-company-betaalt-nederland-274.000.000-usdollar); zie ook over het beleid dat uit de persberichten valt te destilleren: A.J.M. de Swart, F. Mattheijer, 'Zelfmelding en meewerken, wat schuift het?', Tijdschrift voor Sanctierecht \& Onderneming 2018 nr. 2, p. 97-103.

11. Antwoord Minister van Veiligheid en Justitie op Kamervragen, brief 6 september 2019, kenmerk 2662527, p. 2.

12. Antwoord Minister van Veiligheid en Justitie op Kamervragen, brief 6 september 2019, kenmerk 2662527, p. 2.

13. Antwoord Minister van Veiligheid en Justitie op Kamervragen, brief 6 september 2019, kenmerk 2662527, p. 4.

14. Antwoord Minister van Veiligheid en Justitie op Kamervragen, brief 6 september 2019, kenmerk 2662527, p. 5.

15. Antwoord Minister van Veiligheid en Justitie op Kamervragen over de betrouwbaarheid en volledigheid van zelfonderzoek door eigen advocaten van bedrijven, brief 8 april 2020, 2869478, p. 3. 


\section{FCPA Corporate Enforcement Policy in de VS}

\subsection{Incentives opgenomen in de FCPA Corporate Enforcement Policy}

Een bedrijf dat in de VS overgaat tot zelfmelding, ${ }^{16}$ 'volledige medewerking' verleent aan het onderzoek en herstelmaatregelen treft (remediation), kan op basis van de FCPA Corporate Enforcement Policy strafrechtelijke vervolging voorkomen (middels een declination), mits het wederrechtelijk verkregen voordeel wordt terugbetaald. Indien sprake is van ernstige omstandigheden waardoor wel een strafrechtelijke sanctie dient te volgen (bijvoorbeeld betrokkenheid van het management of recidive), komt de onderneming in aanmerking voor een matiging van de sanctie tot 50 procent. Het sanctiebedrag waar deze matiging op wordt toegepast, betreft de ondergrens van de bandbreedte zoals deze kan worden berekend door toepassing van de US Sentencing Guidelines. ${ }^{17}$

Een onderneming die niet tijdig is overgegaan tot zelfmelding kan nog aanspraak maken op een korting tot 25 procent, indien aan alle voorwaarden is voldaan (zie hierna). ${ }^{18}$

\subsection{Voorwaarden waar medewerking aan moet voldoen}

'Volledige medewerking' houdt in de Amerikaanse context in dat de onderneming alle relevante feiten die zijn verzameld tijdens 'a company's independent investigation' en de specifieke bronnen waarop de feiten zijn gebaseerd, deelt met de autoriteiten. ${ }^{19}$ Tevens dienen alle feiten met betrekking tot het mogelijk strafrechtelijk handelen door management, werknemers of agenten te worden geopenbaard, alsook het mogelijk strafbaar handelen van derden. Om mogelijk vervolging te voorkomen of aanspraak te maken op matiging van de sanctie, wordt op basis van het beleid een proactieve en tijdige medewerking verwacht. Dat houdt in dat de onderneming ook aan de de Department of Fustice ('DOf') bericht waar mogelijk bewijsmateriaal kan worden gevonden, alsook medewerking verleent aan het verzamelen en verstrekken van relevante documenten in

16. Zelfmelding (self-disclosure of self-report) vereist in de VS dat de onderneming zelf tijdig de onregelmatigheid meldt bij de Department of Justice ('DOJ'). Tijdig betekent in dit verband in de VS dat de melding moet worden gedaan voordat sprake is van een 'imminent threat' van het bekend worden van deze onregelmatigheid of reeds sprake is van een overheidsonderzoek.

17. Guidelines van de United States Sentencing Commission, https:// www.ussc.gov/guidelines, waarin specifieke richtlijnen worden gegeven over de hoogte van een op te leggen sanctie.

18. FCPA Corporate Enforcement Policy, 2. Limited Credit for Full Cooperation and Timely and Appropriate Remediation in FCPA Matters Without Voluntary Self-Disclosure.

19. In de FCPA Corporate Enforcement Policy is opgenomen dat de informatie verstrekt dient te worden, zolang dat geen schending oplevert van het advocaat-cliëntprivilege. Hoe in de verschillende jurisdicties wordt omgegaan met het advocaat-cliëntprivilege valt buiten het bestek van dit artikel. het buitenland (waaronder in jurisdicties die niet direct toegankelijk zijn voor de autoriteiten). ${ }^{20}$ Van de onderneming wordt voorts verwacht dat zij haar management en medewerkers beschikbaar maakt voor interviews, ook - indien mogelijk en passend - medewerkers die zich in het buitenland bevinden. Voorts wordt van de onderneming verwacht dat zij herstelmaatregelen treft en haar compliancemaatregelen aanscherpt, om soortgelijke strafbare feiten in de toekomst te voorkomen. ${ }^{21}$ Tot slot wordt van de onderneming verwacht dat zij - indien daartoe door de $D O \mathcal{F}$ verzocht - voorkomt dat conflicten ontstaan met het strafrechtelijk onderzoek bij het uitvoeren van het interne onderzoek.

\section{Corporate Co-operation Guidance in het VK}

\subsection{Geen concrete incentives opgenomen in het beleid}

Als uitgangspunt wordt in het VK gehanteerd dat een 'genuinely proactive approach' van het management, nadat het op de hoogte raakt van een onregelmatigheid, een factor is die wordt meegewogen bij de beoordeling van de zaak en kan meebrengen dat niet tot strafvervolging wordt overgegaan. ${ }^{22}$ De Corporate Co-operation Guidance $^{23}$ gepubliceerd door de Serious Fraud Office (hierna: 'SFO') maakt evenwel duidelijk dat zelfs ' $f u l l$, robust co-operation' geen garantie biedt op een bepaalde uitkomst. ${ }^{24}$ Concrete incentives ontbreken dan ook in het beleid.

\subsection{Voorwaarden waar medewerking aan moet voldoen}

Hoewel het VK-beleid geen incentives bevat waarop een onderneming aanspraak kan maken, bevat het beleid wel gedetailleerde richtlijnen waar medewerking uit dient te bestaan. Medewerking aan het onderzoek houdt volgens de Corporate Co-operation Guidance in dat een onderneming ondersteuning verleent aan de $S F O$ die verder gaat dan wat conform de wet vereist is. Het omvat bijvoorbeeld het identificeren van vermeende onregelmatigheden en strafbaar handelen, alsook de personen

20. FCPA Corporate Enforcement Policy, 3b. Full Cooperation in FCPA Matters. FCPA Corporate Enforcement Policy, 2. Limited Credit for Full Cooperation and Timely and Appropriate Remediation in FCPA Matters Without Voluntary Self-Disclosure.

21. FCPA Corporate Enforcement Policy, c. Timely and Appropriate Remediation in FCPA Matter.

22. In de Corporate Co-operation Guidance wordt verwezen naar de Guidance on Corporate Prosecutions en de Deferred Prosecution Agreements Code of Practice waarin dit wordt uiteengezet (DPA Code 2.8.2(i)).

23. De Corporate Co-operation Guidance is op 19 augustus 2019 gepubliceerd in het SFO Operational Handbook, https://www.sfo.gov.uk/ publications/guidance-policy-and-protocols/sfo-operationalhandbook/.

24. De Corporate Co-operation Guidance is op 19 augustus 2019 gepubliceerd in het SFO Operational Handbook, https://www.sfo.gov.uk/ publications/guidance-policy-and-protocols/sfo-operationalhandbook/. 
verantwoordelijk voor dit handelen. Het bewijs dient bewaard en beschikbaar gemaakt te worden voor de $S F O$, waarbij het in gestructureerde vorm an de $S F O$ aangeleverd dient te worden. ${ }^{25}$ Ook wordt van de onderneming verwacht dat zij relevant materiaal identificeert dat zich bevindt bij derden, en faciliteert dat dit materiaal ook beschikbaar wordt gemaakt voor de $S F O .^{26} \mathrm{Om}$ belemmering van het strafrechtelijk onderzoek door de $S F O$ te voorkomen, dient de onderneming de $S F O$ tijdig te informeren voordat zij in het kader van het interne onderzoek mogelijke getuigen of verdachten laat interviewen of disciplinaire acties treft tegen werknemers. ${ }^{27}$ Ook geldt dat werknemers en - indien mogelijk - agenten beschikbaar dienen te worden gemaakt voor interviews met de $S F O$, en de onderneming dient te regelen dat zij hiertoe terugkeren naar het $\mathrm{VK}$ indien nodig. ${ }^{28}$

\section{Kader opgenomen in het Duitse conceptwetsvoorstel}

\subsection{Inleiding}

In Duitsland is een wetsvoorstel in ontwikkeling om rechtspersonen strafrechtelijk te kunnen vervolgen. ${ }^{29}$ Op 22 april 2020 publiceerde het Duitse Federale ministerie van Justitie een concept-ontwerpwetsvoorstel, aangezien niet adequaat kon worden gereageerd op ondernemingscriminaliteit (Entwurf eines Gesetzes zur Stärkung der Integrität in der Wirtschaft, hierna: 'het Duitse conceptwetsvoorstel'). ${ }^{30}$ Hoewel het slechts een concept betreft en dus nog aan wijziging onderhevig kan zijn, bevat het Duitse conceptwetsvoorstel interessante elementen voor een beschouwing in de Nederlandse context. Uit de toelichting op het Duitse conceptwetsvoorstel blijkt dat het op dit moment in Duitsland nog onduidelijk is onder welke voorwaarden het uitvoeren van interne onderzoeken tot matiging van de sanctie kan leiden en welke rechten werknemers hebben wanneer ze worden geinterviewd door onderzoekers. ${ }^{31}$ Tevens volgt uit de toelichting dat - mede vanwege de sterke invloed vanuit de VS - het aantal interne onderzoeken in Duitsland aanzienlijk is toegenomen, waarmee ook het belang toeneemt om de verhouding tussen de

25. Corporate Co-operation Guidance, p. 2, paragraph 1, sub v (a).

26. Corporate Co-operation Guidance, p. 2, paragraph 1, sub viii.

27. Corporate Co-operation Guidance, p. 4, paragraph 6, sub i.

28. Corporate Co-operation Guidance, p. 4, paragraph 6, sub iv

29. Op dit moment kunnen aan rechtspersonen enkel administratieve boetes worden opgelegd van maximaal $€ 10$ miljoen op grond van het Gesetz über Ordnungswidrigkeiten

30. Het Duitse conceptwetsvoorstel werd in augustus 2019 openbaar met als titel Entwurf eines Gesetzes zur Bekämpfung der Unternehmenskriminalität, maar is op 22 april 2020 door het Bundesministerium der Justiz und für Verbraucherschutz officieel gepubliceerd, waarbij door de Duitse federale staten en ondernemingen gereageerd kan worden op het ontwerp tot 12 juni 2020. Het Duitse wetsvoorstel kan worden gevonden via: https://www.bmjv.de/SharedDocs/Gesetzgebungs verfahren/DE/Staerkung_Integritaet_Wirtschaft.html.

31. Toelichting op het Duitse conceptwetsvoorstel, p. 97 vervolgende autoriteiten en de privaatrechtelijke onderzoekers (de onderneming of door haar ingeschakelde adviseurs) te verduidelijken. ${ }^{32}$

\subsection{Incentives voor de onderneming bij het} (laten) uitvoeren van een intern onderzoek

Uit de toelichting op het Duitse conceptwetsvoorstel blijkt dat het niet de bedoeling is dat interne onderzoeken het strafrechtelijk onderzoek van de vervolgende autoriteit vervangen. Interne onderzoeken kunnen volgens de toelichting op het wetsvoorstel - met name op het gebied van witteboordencriminaliteit ${ }^{33}$ - opheldering van de feiten door de gerechtelijke autoriteiten ondersteunen en hieraan een waardevolle bijdrage leveren. ${ }^{34}$

Het Duitse conceptwetsvoorstel bevat om die reden verschillende incentives voor bedrijven die een intern onderzoek (laten) uitvoeren naar onregelmatigheden. Er is volgens de toelichting sprake van een trapsgewijs beloningssysteem. De meest verstrekkende mogelijkheid is om af te zien van vervolging (al dan niet onder voorwaarden). Ook kan de vervolgende autoriteit de rechter verzoeken een schriftelijke sanctie vast te stellen zonder openbare terechtzitting. ${ }^{35}$ De toelichting maakt evenwel niet duidelijk wanneer een onderneming in aanmerking komt voor het afzien van vervolging of vaststellen van een sanctie door de rechter buiten een zitting om. Uit de toelichting op het voorstel blijkt dat de onderneming geen afdwingbaar recht toekomt om niet strafrechtelijk vervolgd te worden indien zij haar medewerking verleent aan een strafrechtelijk onderzoek. ${ }^{36}$

Waar een onderneming wel aanspraak op kan maken indien de vervolgende instantie ondanks volledige medewerking besluit tot strafvervolging, is een matiging van de door de rechter op te leggen sanctie met 50 procent. ${ }^{37}$ De rechter dient in het geval van volledige medewerking deze korting toe te passen. Het Duitse conceptwetsvoorstel bevat geen beleid vergelijkbaar aan de $U S$ Sentencing Guidelines, waarmee de bandbreedte van de strafoplegging in een specifieke zaak vooraf kan worden bepaald. Wel volgt uit het in het wetsvoorstel beschreven systeem welke sanctie aan een onderneming kan worden opgelegd voor een specifiek feit. Ook is de oplegging van bepaalde sancties uitgesloten in geval van medewerking, zoals ontbinding van de onderneming en openbaarmaking van de veroordeling. ${ }^{38}$ Deze sancties zijn volgens de toelichting niet passend bij een onder-

32. Toelichting op het Duitse conceptwetsvoorstel, p. 97

33. Door deze formulering laat de toelichting op het wetsvoorstel de ruimte om ook op andere gebieden dan witteboordencriminaliteit interne onderzoeken te laten uitvoeren.

34. Toelichting op het Duitse conceptwetsvoorstel, p. 99.

35. § 36 (Absehen von der Verfolgung wegen Geringfügigkeit), § 37 (Absehen von der Verfolgung unter Auflagen und Weisungen), § 10 (Verwarnung mit Verbandsgeldsanktionsvorbehalt) en $\S 51$ (Sanktionsbescheid) van het Duitse conceptwetsvoorstel.

36. Toelichting op het Duitse conceptwetsvoorstel, p. 99

37. Toelichting op het Duitse conceptwetsvoorstel, p. 98

38. § 19 van het Duitse conceptwetsvoorstel. 
neming die medewerking heeft verleend aan het strafrechtelijk onderzoek. ${ }^{39}$

\subsection{Voorwaarden waar medewerking aan moet voldoen}

Om in aanmerking te komen voor een matiging van de sanctie, dient volgens het Duitse conceptwetsvoorstel aan een aantal voorwaarden te zijn voldaan. Zo dient een wezenlijke bijdrage te zijn geleverd door de onderneming of door de door haar ingeschakelde derde aan het ophelderen van het strafbare feit gepleegd door de onderneming. De onderneming of de door haar ingeschakelde derde dient voortdurend en zonder enige beperking samen te werken met de vervolgende autoriteiten. Dit kan bijvoorbeeld bestaan uit het verschaffen van tussentijdse verslagen en uitgebreide antwoorden op vragen van de vervolgende instanties. Het interne onderzoek dient op een wijze uitgevoerd te worden die voorkomt dat bewijs wordt vernietigd en het risico op valse verklaringen moet worden beperkt door aan betrokkenen die voorwerp van onderzoek zijn bepaalde rechten te geven. ${ }^{40}$ Vanwege de verscheidenheid aan interne onderzoeken en de onderliggende feiten kunnen meer gedetailleerde eisen voor de wijze van uitvoering van interne onderzoeken volgens de toelichting niet worden gesteld. ${ }^{41}$

Indien de opsporingsautoriteiten de onderneming tijdens hun strafrechtelijk onderzoek benaderen, kan enkel een sanctiebeperking worden verkregen indien de onderneming onmiddellijk besluit medewerking te verlenen aan het onderzoek door de vervolgende autoriteiten, inclusief het daarbij uitvoeren van een intern onderzoek. ${ }^{42}$ Uiterlijk bij afronding van het interne onderzoek dienen de resultaten van dat onderzoek, alsook alle voor het onderzoek relevante documenten, verstrekt te worden aan de vervolgende autoriteiten. ${ }^{43}$

Het interne onderzoek kan worden uitgevoerd door de onderneming zelf of een ingeschakelde derde. Als voorwaarde geldt op basis van het Duitse conceptwetsvoorstel dat de door de onderneming ingeschakelde derde of personen die namens de ingeschakelde derde als onderzoeker optreden, niet ook namens de verdachte onderneming in een strafrechtelijke procedure optreden. ${ }^{44}$ Deze scheiding dient er volgens de toelichting toe om potentiële conflicten die zouden kunnen ontstaan tussen het uitvoeren van een intern onderzoek en de strafrechtelijke verdediging te voorkomen. ${ }^{45}$ De bepaling laat wel toe dat hetzelfde advocatenkantoor het onderzoek uitvoert én de verdediging voert, zolang

39. Toelichting op het Duitse conceptwetsvoorstel, p. 101

40. Toelichting op het Duitse conceptwetsvoorstel, p. 98

41. Toelichting op het Duitse conceptwetsvoorstel, p. 100.

42. Toelichting op het Duitse conceptwetsvoorstel, p. 100

43. § 18 , onderdeel 1 , sub 1 , sub 3 en sub 4 van het Duitse conceptwetsvoorstel.

44. § 18, onderdeel 1, sub 2, van het Duitse conceptwetsvoorstel.

45. Toelichting op het Duitse conceptwetsvoorstel, p. 100, onder verwijzing naar Leitner/Rosenau-Wimmer, Wirtschafts- und Fiscaal strafrecht, artikel 152 StPO marginaal nr. 16. organisatorische maatregelen worden getroffen om een scheiding tussen die werkzaamheden aan te brengen. ${ }^{46}$

Het onderzoek dient volgens het Duitse conceptwetsvoorstel te worden uitgevoerd in overeenstemming met de beginselen die gelden in een fair trial. Dat houdt in dat:

a. de werknemers voorafgaand aan een interview dienen te worden geinformeerd dat hun verklaring eventueel kan worden gebruikt in strafrechtelijke procedures tegen hen;

b. de geïterviewde het recht krijgt om voorafgaand aan het interview een advocaat of lid van de ondernemingsraad te raadplegen, en hierover te worden geinformeerd; en

c. de geïnterviewde het recht heeft om te weigeren informatie te verstrekken of vragen te beantwoorden waarmee deze zichzelf of familieleden kan blootstellen aan vervolging wegens een misdrijf, en over dit recht voorafgaand aan interview moet worden geïnformeerd. ${ }^{47}$

Er geldt geen verplichting om interne onderzoeken conform deze regels uit te voeren. Maar interne onderzoeken kunnen volgens de toelichting op het Duitse conceptwetsvoorstel enkel een mitigerende werking hebben op de op te leggen sanctie, wanneer deze zijn uitgevoerd conform deze regels. ${ }^{48}$

Uit de toelichting volgt dat de achtergrond van deze bepalingen is dat een onderzoek anders niet voldoet aan de waarborgen die gelden in de rechtstaat. Indien getuigen onder druk worden gezet om een verklaring af te leggen, doet dat volgens de toelichting afbreuk aan de bewijswaarde. Indien een geïnterviewde verplicht wordt een verklaring af te leggen waarmee deze zichzelf of zijn familie kan belasten, dan levert dat een sterk motief op om een valse verklaring af te leggen, aldus de toelichting. ${ }^{49}$ Ondernemingen met interne onderzoeken waarin verklaringen onder dwang zijn afgelegd komen niet in aanmerking voor matiging van sanctietoepassing. Wanneer de overheid ondernemingen wel zou belonen en daarmee zou aanmoedigen dat verklaringen onder dwang worden afgelegd, zou dat volgens de toelichting een ontoelaatbare inmenging opleveren door de overheid in de rechten van de betrokken werknemer. ${ }^{50}$

46. Toelichting op het Duitse conceptwetsvoorstel, p. 100; J. Bielefeld, A. Schmid, T. Handel, 'Verbandssanktionengesetz: Klimawandel bei Unternehmenssanktionen', 17 oktober 2019, https:// www.lexology.com/library/detail.aspx?g=41a1b534-0a79-44ea-ad69cof48dfa9864; T. Wybitul, prof. dr. T. Grützner, 'Gesetzentwurf zur Bekämpfung der Unternehmenskriminalität bringt neue Regeln für interne Untersuchungen - Datenschutz gewinnt große Bedeutung', 26 augustus 2019, https://www.lathamgermany.de/2019/08/ gesetzentwurf-zur-bekampfung-der-unternehmenskriminalitat-bringtneue-regeln-fur-interne-untersuchungen-datenschutz-gewinnt-grosebedeutung/.

47. § 18, onderdeel 1, sub 5, van het Duitse conceptwetsvoorstel

48. Toelichting op het Duitse conceptwetsvoorstel, p. 101.

49. Toelichting op het Duitse conceptwetsvoorstel, p. 101.

50. Toelichting op het Duitse conceptwetsvoorstel, p. 102. 


\section{Beoordeling: welk kader past het best bij de Nederlandse context?}

\subsection{Inleiding}

Indien het $\mathrm{OM}$ en de minister bedrijven willen stimuleren tot zelfmelding en medewerking aan een strafrechtelijk onderzoek, is het wenselijk dat het OM vastlegt waar bedrijven aanspraak op kunnen maken indien zij hiertoe overgaan. Hoewel voor ondernemingen ook andere argumenten voor zelfmelding en medewerking aan een onderzoek kunnen gelden (zoals het belang om in een korter tijdsbestek inzicht te krijgen in de feiten om schoon schip te kunnen maken), zal zonder duidelijkheid over de incentives waar zij aanspraak op kunnen maken onzekerheid bij ondernemingen blijven bestaan over het effect dat de opstelling die de onderneming kiest zal hebben op het strafrechtelijk onderzoek. De Swart en Matthijer pleitten in 2018 reeds voor een vastlegging van beleid, waarin de eisen aan zelfmelding, medewerking en herstelmaatregelen worden vastgelegd, alsook - op hoofdlijnen - de bijbehorende incentives. ${ }^{51}$ Hoewel uit de gepubliceerde hoge transacties wel is af te leiden welke elementen positief meewegen, zal een helder beleid met concrete incentives meer houvast bieden en daardoor een betere stimulans zijn.

\subsection{Mogelijke incentives in Nederlands beleid}

Zowel het beleid in de VS als het Duitse conceptwetsvoorstel bieden concrete incentives waar een onderneming aanspraak op kan maken. In het beleid van het VK zijn geen concrete incentives opgenomen. Het beleid in de VS biedt aan ondernemingen vooraf de meeste duidelijkheid over de mogelijkheid om strafrechtelijke vervolging te voorkomen. Het Duitse systeem benoemt wel uitdrukkelijk de mogelijkheid voor buitengerechtelijke afdoening, maar maakt niet inzichtelijk wanneer een gang naar de rechter wordt voorkomen. Aangezien naar mijn beoordeling ondernemingen behoefte hebben aan duidelijkheid, heeft het FCPA-beleid op dit punt mijn voorkeur. Vertaald naar de Nederlandse context, kan het beleid van het OM bevatten dat een onderneming die tot zelfmelding overgaat en volledige medewerking verleent, een schikking kan treffen in de zin van artikel 511c Sv ter hoogte van (enkel) het wederrechtelijk verkregen voordeel, tenzij sprake is van ernstige omstandigheden (bijvoorbeeld recidive) die daaraan in de weg staan. Een betaling ter voorkoming van strafvervolging - in OM-persberichten veelal angeduid als een boete ${ }^{52}-$ blijft achterwege. In het beleid kunnen zwaarwegende omstandigheden

51. J.M. de Swart, F. Mattheijer, 'Zelfmelding en meewerken, wat schuift het', Tijdschrift voor Sanctierecht \& Onderneming 2018 nr. 2, p. 97-103.

52. Deze kwalificatie is juridisch niet correct. Dit betreft een betaling aan de staat van een geldsom ter voorkoming van strafvervolging, als bedoeld in artikel 74, tweede lid, sub a, Sr. worden opgenomen die aan deze wijze van afdoening in de weg staan, net als in de Amerikaanse context.

In gevallen waarin zelfmelding niet meer mogelijk is, of zwaarwegende omstandigheden aan de hiervoor genoemde wijze van afdoening in de weg staan, wordt het ingewikkelder om soortgelijk beleid toe te passen in de Nederlandse context vanwege het ontbreken van richtlijnen vergelijkbaar met de US Sentencing Guidelines. Uiteraard bestaat de mogelijkheid om het beleid van de VS te vertalen naar het Nederlandse beleid, door - bij het aangaan van een transactie - een korting toe te passen van 50 procent, of op zitting de strafeis te halveren. Bij het ontbreken van richtlijnen hoe hoog het transactiebedrag of de strafeis zonder medewerking zou zijn geweest, kan een onderneming in het ongewisse blijven of deze daadwerkelijk een korting heeft ontvangen, of dat het $\mathrm{OM}$ - rekening houdend met de op basis van het beleid nog toe te passen korting - het transactiebedrag of de strafeis op een hoger niveau heeft bepaald (waardoor de onderneming de facto geen of geen volledige korting heeft ontvangen).

Het systeem zoals opgenomen in het Duitse conceptwetsvoorstel kan in de Nederlandse context niet goed worden toegepast, aangezien daarin aan de rechter een verplichting wordt opgelegd om de straf te halveren. Dat zou een afwijking opleveren van de Nederlandse systematiek, waarbij de rechter de straf bepaalt en het daarbij vrijstaat af te wijken van de strafeis van het OM. Dat betekent overigens wel dat een onderneming - ook bij een lagere strafeis van het $\mathrm{OM}$ op grond van het hiervoor gesuggereerde beleid - het risico loopt om desondanks een hogere straf opgelegd te krijgen. Dat risico is niet weg te nemen zonder fundamentele wijziging van het Nederlandse strafrechtsysteem en lijkt daardoor minder aangewezen.

\subsection{Voorwaarden waar medewerking aan moet voldoen}

Het uitgangspunt dat in alle systemen wordt gevolgd, is dat de onderneming volledige medewerking dient te verlenen en resultaten van haar eigen onderzoek ter beschikking dient te stellen aan de autoriteiten. Binnen verschillende systemen bestaan uiteraard nuanceverschillen, maar de strekking dat de onderneming dient bij te dragen aan opheldering van de feiten komt in zowel de VS, het VK als het Duitse conceptwetsvoorstel terug. Het $\mathrm{OM}$ zou in het beleid kunnen vastleggen welke mate van medewerking wordt verwacht, waarbij ook aan de orde kan komen in hoeverre wordt verwacht dat het OM informatie aanlevert over betrokkenheid van individuen en op welke wijze wordt voorkomen dat het interne onderzoek het strafrechtelijk onderzoek doorkruist. De VS en het VK hanteren kort samengevat als uitgangspunt dat ook informatie moet worden verstrekt over betrokkenheid van natuurlijke personen bij het strafbare gedrag. Dat komt niet terug in het Duitse conceptwetsvoorstel, waarbij enkel de feiten dienen te worden verstrekt ter opheldering van overtredingen begaan door de onderneming. Vanuit het perspectief 
van de onderneming bezien zou het voldoende moeten zijn dat deze inzichtelijk maakt welk strafbaar gedrag de onderneming kan worden verweten, waarbij minder relevant is welke specifieke personen daarin een bepaalde rol hebben gehad. Het OM zal evenwel gebaat zijn met zoveel mogelijk informatie, waaronder ook informatie over de betrokkenheid van individuen bij de strafbare gedragingen.

Het Duitse conceptwetsvoorstel wijkt af van het beleid in de VS en het VK, door eisen te stellen aan de wijze waarop de onderneming het interne onderzoek moet laten uitvoeren om in aanmerking te kunnen komen voor matiging.

Op basis van het Duitse conceptwetsvoorstel kan dezelfde advocaat niet het onderzoek uitvoeren, alsook de verdediging voeren. Het beleid in de US en het VK bevat geen beperkingen of voorwaarden aan de partij die het onderzoek uitvoert. De minister heeft zich hierover reeds uitgesproken en staat een dergelijke beperking niet voor.

Een ander belangrijk vereiste in het Duitse conceptwetsvoorstel betreft de verplichting om aan betrokkenen in het onderzoek het recht te geven om geen antwoord te geven op vragen, indien deze zich kunnen incrimineren. Een dergelijk uitgangspunt kent het beleid in de VS en het VK niet. In mei 2019 leidde een uitspraak van een US District Court tot veel discussie, nadat de rechter - kort samengevat - concludeerde dat een verklaring afgelegd in een intern onderzoek niet tegen de betrokkene in een strafrechtelijke procedure kan worden gebruikt, indien de overheid het interne onderzoek heeft aangestuurd. ${ }^{53}$ Beleid in de VS ontbreekt op dit onderwerp evenwel en het is nog de vraag of de hiervoor aangehaalde uitspraak navolging zal vinden of een uitzondering betreft vanwege de specifieke casus die hieraan ten grondslag lag. ${ }^{54}$

De minister is helder in het standpunt dat hij niet voornemens is formele richtlijnen op te leggen waar een interne onderzoeker zich aan moet houden. Hij volstaat met een verwijzing naar de tuchtrechtelijke regels. Als algemeen uitgangspunt geldt volgens de tuchtrechter dat het aan de vrije bepaling van de advocaat en de cliënt is hoe een intern onderzoek wordt ingericht en waaruit het moet bestaan. Indien echter op voorhand duidelijk is dat de inhoud van het rapport ook wordt

53. United States District Court, Southern District of New York, US v. Matthey Connolly and Gavin Campbell Black, 2 May 2019, no. 16, Cr. $0370(C M)$, onder verwijzing naar: United States v. Stein ('Stein I'), 435 F.Supp.2d 330 (2006) at 353 en United States v. Stein ('Stein II'), 440 F.Supp.2d 315 (2006) at 334.

54. Uit de uitspraak bleek dat nauw contact bestond tussen de autoriteiten, Deutsche Bank en het advocatenkantoor dat het interne onderzoek uitvoerde, waarbij de overheid ook instructies gaf met betrekking tot de uitvoering van het onderzoek. De rechter oordeelde dat de verdachte overtuigend had aangetoond dat het onderzoek door Deutsche Bank en het door haar ingeschakelde advocatenkantoor kon worden toegerekend aan de overheid, en zodoende dat de betrokkene op grond van de Garrity rights niet gedwongen had mogen worden een verklaring af te leggen in het interne onderzoek. gebruikt voor externe verantwoording, moeten aan de totstandkoming en aan de inhoud van een rapport onder meer met het oog op de daarbij mogelijk betrokken belangen van derden zware eisen worden gesteld, aldus de tuchtrechter. ${ }^{55} \mathrm{Bij}$ het voorgaande past mijns inziens dat voorafgaand aan het interview het voor de betrokkene duidelijk dient te zijn in welk kader het interview plaatsvindt. Indien het voornemen bij de onderneming bestaat om de resultaten van het interne onderzoek te verstrekken aan de FIOD en het OM, past bij deze zorgvuldigheid dat de betrokkene hierover wordt geinformeerd. Tevens zou als gebruik kunnen worden ontwikkeld om personen die worden geinterviewd te informeren over de mogelijkheid om een advocaat te raadplegen, zodat deze zich adequaat kunnen laten voorlichten.

Het dilemma dat de Duitse wetgever poogt op te lossen, bestaat ook in de Nederlandse context en wordt via het tuchtrecht niet verholpen. Uit het tuchtrecht kan mijns inziens namelijk geen verplichting volgen voor een interne onderzoeker om aan een betrokkene het recht te geven geen antwoord te geven op vragen waar deze zichzelf mee kan incrimineren. Een door de betrokkene ingeschakelde advocaat kan de betrokkene informeren en adviseren. Het is evenwel niet duidelijk of het niet meewerken aan een intern onderzoek vanwege de vrees op zelfincriminatie kan leiden tot een rechtmatig ontslag. Niet uitgesloten is dat de rechter in arbeidsrechtzaken het belang van de werknemer zwaarder laten wegen, in gevallen waar op voorhand duidelijk is dat de resultaten van het onderzoek met de FIOD en het OM worden gedeeld. ${ }^{56}$ Ook is onduidelijk of de strafrechter verklaringen buiten beschouwing zal laten, indien deze in de context van een intern onderzoek wegens vrees voor arbeidsrechtelijke consequenties zijn afgelegd. ${ }^{57}$ Hoewel het wellicht onbevredigend is voor de in het onderzoek betrokken personen dat hierover geen zekerheid bestaat, lijkt in de Nederlandse context geen goede basis te bestaan om van een private onderzoeker te eisen een recht te geven aan in het onderzoek betrokken personen om geen vragen te beantwoorden indien deze zichzelf kunnen incrimineren (vergelijkbaar met de cautie). Hoe moet worden omgegaan met de positie van de betrokkene, zal daardoor - net als in de Amerikaanse

55. Raad van Discipline Amsterdam 18 december 2018, ECLI:NL: TADRAMS:2017:276. Zie hierover uitgebreider: J. Leliveld, 'Een begin van normering van interne onderzoeken door advocaten', Sdu Blog 4 januari 2018, https://www.sdu.nl/blog/een-begin-van-normering-vaninterne-onderzoeken-door-advocaten.html.

56. De rechter heeft zich voor zover mij bekend nog niet uitgelaten over een besluit van een werknemer om geen medewerking te verlenen aan een intern onderzoek vanwege dit risico op zelfincriminatie, in een onderzoek waarvan op voorhand vaststond dat de resultaten aan de FIOD en het OM zouden worden verstrekt. In oudere jurisprudentie werd in enkele uitspraken wel geoordeeld dat het niet verlenen van medewerking het gegeven ontslag kon rechtvaardigen, zie hierover: H.J.Th. Biemond, F.C.A. van de Bult en A.P.P. Witteveen, 'De positie van werkgever en werknemer bij een intern onderzoek', TVA\&O maart 2013, p. 10-19.

57. Het onderwerp kwam enkel zijdelings aan de orde in de beschikking van Gerechtshof Den Haag 19 mei 2015, ECLI:NL:GHDHA:2015:1204. 
context - in de rechtspraak moeten worden uitgekristalliseerd.

Het aanscherpen van compliancemaatregelen en treffen van herstelmaatregelen (remediation) kan - vergelijkbaar aan de voorwaarden in de VS - ook deel uitmaken van het door het OM vast te stellen beleid. Dat draagt bij aan het voorkomen van herhaling van onregelmatigheden.

\section{Conclusie}

Zowel de minister als het OM staan positief tegenover ondernemingen die medewerking verlenen en besluiten een intern onderzoek te laten uitvoeren om helderheid te krijgen over de geconstateerde onregelmatigheden. Intern onderzoek namens ondernemingen draagt volgens de minister bij aan een op ' $z o$ effectief en efficiënt mogelijke wijze' afwikkelen van complexe fraudezaken en het $\mathrm{OM}$ wil vaker gebruik maken van door advocaten en accountants voor ondernemingen uitgevoerde onderzoeken. Hoewel uit de gepubliceerde hoge transacties wel is af te leiden welke elementen het OM positief meeweegt, zal een helder beleid met concrete incentives meer houvast bieden en daardoor een betere stimulans zijn voor ondernemingen om over te gaan tot zelfmelding en medewerking aan het strafrechtelijk onderzoek.

Uit een vergelijking tussen de kaders zoals deze worden gehanteerd in de VS, het VK en het Duitse conceptwetsvoorstel blijkt dat in de VS aan ondernemingen vooraf de meeste duidelijkheid wordt geboden over de incentives waar zij aanspraak op kunnen maken indien volledige medewerking wordt verleend aan het strafrechtelijk onderzoek. Vergelijkbaar beleid als opgenomen in de FCPA Corporate Enforcement Policy kan relatief eenvoudig worden vertaald naar de Nederlandse context in een vastlegging van beleid door het OM. Om dit beleid adequaat door te voeren, is het mijns inziens raadzaam om ook richtlijnen vergelijkbaar aan de $U S$ Sentencing Guidelines vast te leggen, zodat ook helderheid bestaat over de hoogte van het bedrag waarop een procentuele matiging wordt toegepast.

De minister heeft uitgesproken geen formele richtlijnen op te willen leggen aan interne onderzoekers. Het zal mede om die reden niet waarschijnlijk zijn dat in Nederland regels worden ingevoerd zoals opgenomen in het Duitse conceptwetsvoorstel. Het Duitse conceptwetsvoorstel geeft wel aanleiding voor een nadere discussie hoe om te gaan met de belangen van in het interne onderzoek betrokken personen, en meer specifiek het risico op zelfincriminatie. $\mathrm{Nu}$ een vastlegging van formele richtlijnen voor interne onderzoekers over de wijze waarop een onderzoek moet worden uitgevoerd niet in de verwachting ligt, zal dit onderwerp mijns inziens in de jurisprudentie van de tuchtrechter, arbeidsrechter en strafrechter verder uitgekristalliseerd moeten worden. 